\title{
Journal of Drug
}

\section{Targeting Apoptosis, Advanced Glycation End Products and Transforming Growth Factor- $\beta 1$ by Biguanides and Resveratrol to Ameliorate Experimentally-induced Diabetic Nephropathy}

\author{
Ahmed M. Kabel ${ }^{1,2^{*}}$, Mohamed S. Omar ${ }^{3,4}$ and Hany M. Borg ${ }^{5}$ \\ ${ }^{1}$ Department of Clinical Pharmacy, College of Pharmacy, Taif University, Taif, Saudi Arabia \\ ${ }^{2}$ Department of Pharmacology, Faculty of Medicine, Tanta University, Tanta, Egypt \\ ${ }^{3}$ Division of Biochemistry, Pharmacology and Toxicology Department, College of Pharmacy, Taif University, Taif, Saudi Arabia \\ ${ }^{4}$ Chemistry Department, Faculty of Science, Benha University, Benha, Egypt \\ ${ }^{5}$ Department of Physiology, Faculty of Medicine, Kafrelsheikh University, Egypt
}

\begin{abstract}
*Corresponding author: Dr. Ahmed M. Kabel, Department of Clinical Pharmacy, College of Pharmacy,Taif University, Al-Haweiah, PO Box 888, Zip Code 21974, Saudi Arabia; Tel: +201009041488 or+966564833526; Email: drakabel@gmail.com

Article Type: Research, Submission Date: 5 October 2015, Accepted Date: 21 November 2015, Published Date: 14 December 2015.

Citation: Ahmed M. Kabel, Mohamed S. Omar and Hany M. Borg (2015) Targeting Apoptosis, Advanced Glycation End Products and Transforming Growth Factor- $\beta 1$ by Biguanides and Resveratrol to Ameliorate Experimentally-induced Diabetic Nephropathy. J. Drug 1(1): 1-9. doi: https://doi.org/10.24218/jod.2015.1.
\end{abstract}

Copyright: @ 2015 Ahmed M. Kabel. This is an open-access article distributed under the terms of the Creative Commons Attribution License, which permits unrestricted use, distribution, and reproduction in any medium, provided the original author and source are credited.

\begin{abstract}
Background: Diabetic nephropathy is one of the complications of diabetes caused by angiopathy of capillaries in the renalglomeruli. Its mechanisms may include glycosylation of renal proteins, abnormal intrarenal hemodynamics and hypertension. Resveratrol is a natural compound found in grapes and red wine that offers protective effects against many cardiovascular diseases and cancer. Metformin is a biguanide that is considered as the first-line drug for treatment of type 2 diabetes.
\end{abstract}

Objective: To study the effect of each of resveratrol and metformin alone and in combination on streptozotocin (STZ)induced diabetic nephropathy.

Methods: 100 male Wistar rats were divided into 5 equal groups: Control untreated group, STZ group, STZ + Metformin group, STZ + Resveratrol group, and STZ + Resveratrol + Metformin group. Kidney weight/body weight ratio, serum fasting glucose, glycosylated $\mathrm{Hb}$, blood urea, serum creatinine and creatinine clearance were determined. A part of the kidney was homogenized for determination of tissue tumor necrosis factor alpha (TNF- $\alpha$ ), transforming growth factor beta 1 (TGF- $\beta 1$ ), nitric oxide (NO), reduced glutathione (GSH), advanced glycation end products (AGEs) and caspase-3 activity. The other part was subjected to histopathological examination.

Results: Both resveratrol and metformin alone and in combination induced significant increase in creatinine clearance, tissue GSH and tissue caspase-3 activity with significant decrease in kidney weight/body weight ratio, serum fasting glucose, glycosylated $\mathrm{Hb}$, blood urea, serum creatinine, tissue TNF- $\alpha$, TGF- $\beta 1$, $\mathrm{NO}$ and AGEs and alleviated the histopathological changes compared to the group that received STZ alone.
Conclusion: Resveratrol/metformin combination had a protective effect on experimentally-induced diabetic nephropathy in rats.

Key words: Resveratrol,Biguanides,Diabetes,Nephropathy

\section{Introduction}

Diabetic nephropathy (DN) is one of the most frequent life threatening complications of diabetes mellitus that occur in approximately $30-40 \%$ of patients. It is usually attributed to metabolic consequences of abnormal glucose regulation, such as elevated blood and tissue levels of glycosylated proteins and heamodynamic changes within the kidney tissue [1]. The exact mechanisms underlying DN are complex and not well defined. Chronic hyperglycemia, the main determinant of the initiation and propagation of $\mathrm{DN}$, not only generates more reactive oxygen metabolites, but also attenuates anti-oxidative mechanisms through non-enzymatic glycation of the scavenging enzymes. Moreover, hyperglycemia may be toxic either by non-enzymatic reaction of glucose with proteins and subsequent formation of advanced glycosylation end products (AGEs) or by increased metabolism leading to increased oxidative stress and activation of protein kinase $\mathrm{C}$, resulting in increased production of proinflammatory cytokines [2].

Resveratrol is a natural compound found in grapes and red wine. Many studies proved that it had protective effects against cardiovascular diseases, neurodegenerative diseases and cancer. The mechanisms of these beneficial effects are not yet well understood but many studies have reported this to its antioxidant, anti-inflammatory and anti-apoptotic effects [3-5].

Metformin is an antidiabetic agent that decreases intestinal absorption of glucose, increases its anaerobic metabolism, 
Citation: Ahmed M. Kabel, Mohamed S. Omar and Hany M. Borg (2015) Targeting Apoptosis, Advanced Glycation End Products and Transforming Growth Factor- $\beta 1$ by Biguanides and Resveratrol to Ameliorate Experimentally-induced Diabetic Nephropathy. J. Drug 1(1): 1-9. doi: https://doi. org/10.24218/jod.2015.1.

improvesinsulin sensitivity and decreasesglucagon release. Recent investigations showed that metformin prevented the dangerous effects of oxidative stress and free radicals in many cell types, including endothelial cells[6-8].Also, the ability of metformin to modulate several oxidative stress markers and proinflammatory cytokines at the biochemical and gene expression levels may play a role in its renoprotective effect[9]. The aim of this study was to investigate the effect of each of resveratrol and metformin alone and in combination on streptozotocin (STZ)-induced DN in rats. This combination was selected depending on data from the previous studies which suggested that resveratrol had potent antioxidant, anti-inflammatory and anti-apoptotic properties without known adverse effects which may potentiate the effect and decrease side effects of metformin.

\section{Materials and Methods}

\section{Chemicals and drugs}

- Streptozotocin (STZ), metformin and resveratrol were purchased from Sigma Chemical Co (St. Louis, MO, USA). STZ was dissolved in $0.1 \mathrm{M}$ cold citrate buffer ( $\mathrm{PH} 4.5$ ). Metformin was dissolved in normal saline. Resveratrol was suspended in $0.5 \%$ carboxymethyl cellulose solution.

- Commercially available kits, Diamond diagnostics for estimation of blood glucose.

- ELISA kits supplied by RayBiotech, Inc. for determination of TNF- $a$.

- ELISA kits supplied byWuhan EIAab Science Co.,Ltd for determination of advanced glycation end products (AGEs).

- ELISA kits supplied by Uscn Life Science Inc. Wuhan, for determination of Transforming growth factor beta 1 (TGF- $\beta 1$ ).

\section{Animals and groups}

The present study was carried out on 100 male Wistar rats weighing 150-200 grams collected from local source with free access to food and tap water ad libitum through the whole period of the study. All the experiments were conducted according to the National Research Council's guidelines. Animal handling was followed according to Helsinki declaration of animal ethics. Rats were divided into five equal groups each of twenty rats as follows:

Group I: Control untreated group.

Group II: Received a single intraperitoneal injection of STZ in a dose of $65 \mathrm{mg} / \mathrm{kg}[9]$.

Group III: Received a single intraperitoneal injection of STZ (65 $\mathrm{mg} / \mathrm{kg}$ ) then received metformin orally in a dose of $500 \mathrm{mg} / \mathrm{kg} /$ day [9].

Group IV: Received a single intraperitoneal injection of STZ $(65 \mathrm{mg} / \mathrm{kg})$ then received resveratrol orally in a dose of $5 \mathrm{mg} /$ $\mathrm{kg} /$ day[3].

Group V: Received a single intraperitoneal injection of STZ (65 $\mathrm{mg} / \mathrm{kg}$ ) then received metformin orally in a dose of $500 \mathrm{mg} / \mathrm{kg} /$ day concomitantly with resveratrol orally in a dose of $5 \mathrm{mg} / \mathrm{kg} /$ day.

\section{Determination of the biochemical parameters}

One week after STZ injection blood samples were collected from retro-orbital sinus of rats and were used for estimation of serum glucose level. Rats with glucose level above $300 \mathrm{mg} / \mathrm{dL}$ were considered diabetic. Drugs were administered one week after STZ injection and continued for 8 weeks.

At the end of the work, rats were kept in special metabolic cages for 24 hours urine collection. After an overnight fasting, blood samples were taken from retro orbital sinus of rats. Glycosylated $\mathrm{Hb}(\% \mathrm{HB})$ concentration in $50 \mu \mathrm{L}$ of whole blood was measured colorimetrically (Shimadzu Model UV160, Kyoto, Japan) after being separated from unbound hemoglobin using an affinity resin [10]. Blood samples were kept in glass tubes in a water bath for 30 minutes at $37^{\circ} \mathrm{C}$ till blood clotting occurred. Then, serum was separated by centrifugation for 20 minutes to estimate fasting serum glucose level according to the method ofTrinder[11]. Blood urea was measured according to the method of Patton and Crouch [12]. Serum and urinary creatinine was measured according to the method of Henry [13]. Creatinine clearance was calculated by applying the following formula [14]:

Creatinine clearance $(\mathrm{ml} / \mathrm{min} /$ day $)=\mathrm{mg}$ creatinine $/ \mathrm{dl}$ urine $\mathrm{X}$ $\mathrm{ml}$ urine 24 hours

mg creatinine /dl serum $X$ 1440

Rats were sacrificed by decerebration and both kidneys were removed and weighed for determination of kidney weight/body weight ratio. The kidney was divided into two parts; one part was subjected to histopathological examination and the other part was homogenized for determination of tissue TNF- $\alpha$ using ELISA kits according to the instructions of the manufacturer, tissue nitric oxide (NO) (Tissue nitrite and nitrate were estimated as an index of NO production) [15], tissue transforming growth factor (TGF)- $\beta 1$ and advanced glycation end products using ELISA kits according to the instructions of the manufacturer, reduced glutathione (GSH) according to the methodofBeutler et al.[16] and total protein content according to the method of Lowry et al. [17].

\section{Assay of tissue caspase- 3 activity}

A piece of the kidney tissue was homogenised and proteins were extracted and stored at $-80^{\circ} \mathrm{C}$. Activity of caspase- 3 was determined spectrophotometrically as described by Gurtu

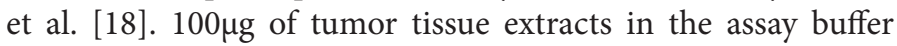
(50mM HEPES, pH 7.4, 100mM NaCl, 0.1\% CHAPS,10mM dithiothreitol,1mM EDTA,10\% glycerol) was added to $100 \mu \mathrm{M}$ of the peptide substrate N-acetyl-Asp-Glu-Val-Asp- $\rho$ nitroanilide (Ac-DEVD- $\rho N A$ ) and incubated at $37^{\circ} \mathrm{C}$ for 1 hour. Cleavage of the substrate was monitored every 30 minutes up to 2 hours at $405 \mathrm{~nm}$ and the enzyme activity was expressed as $\mathrm{nmol} / \mathrm{min} / \mathrm{mg}$ protein.

\section{Histopathological examination}

Sections from the kidney were prepared and stained with hematoxyline and eosin ( $\mathrm{H} \& \mathrm{E})$ and examined by light microscope and apoptotic indices were determined. The counting of the apoptotic indices was performed by one pathologist, and in $20 \%$ of randomly selected cases the counting was repeated by another pathologist. In cases with significant disagreement between results, the counting was performed at the multiheaded microscope by both pathologists. The morphological criteria for 
Citation: Ahmed M. Kabel, Mohamed S. Omar and Hany M. Borg (2015) Targeting Apoptosis, Advanced Glycation End Products and Transforming Growth Factor- $\beta 1$ by Biguanides and Resveratrol to Ameliorate Experimentally-induced Diabetic Nephropathy. J. Drug 1(1): 1-9. doi: https://doi. org/10.24218/jod.2015.1.

apoptotic bodies were applied in our study according to Staunton and Gaffney [19].

\section{Statistical analysis}

Results were expressed as the mean \pm SEM. One-way analysis of variance test (ANOVA) followed by LSD test were used to compare between the different groups. The statistical significance was accepted at a level of p-value less than 0.05.

\section{Results}

\section{Effect of different treatments on serum fasting glucose (Table 1)}

Administration of STZ to rats induced significant increase in serum fasting glucose compared to the normal control group. Administration of metformin or resveratrol induced significant decrease in serum fasting glucose compared to STZ-treated group. The decrease in serum fasting glucose was more significant with metformin/resveratrol group compared to the use of each of these drugs alone.

\section{Effect of different treatments on kidney weight/body weight ratio (Table 2)}

Administration of STZ to rats induced significant increase in kidney weight/body weight ratio compared to the normal control group. Administration of metformin or resveratrol induced significant decrease in kidney weight/body weight ratio compared to STZ-treated group. The decrease in kidney weight/body weight ratio was more significant with metformin/ resveratrol group compared to the use of each of these drugs alone.

\section{Effect of different treatments on glycosylated $\mathrm{Hb}$ (Table 1)}

Administration of STZ to rats induced significant increase in glycosylated $\mathrm{Hb}$ compared to the normal control group. Administration of metformin or resveratrol induced significant decrease in glycosylated $\mathrm{Hb}$ compared to STZ-treated group. The decrease in glycosylated $\mathrm{Hb}$ was more significant with metformin/resveratrol group compared to the use of each of these drugs alone.

\section{Effect of different treatments on the renal functions (Table 1)}

Administration of STZ to rats induced significant increase in blood urea and serum creatinine together with significant decrease in creatinine clearance compared to the control group. Administration of metformin or resveratrol induced significant decrease in blood urea and serum creatinine together with significant increase in creatinine clearance compared to STZtreated group. The decrease in blood urea and serum creatinine together with the increase in creatinine clearance was more significant with metformin/resveratrol group compared to the use of each of these drugs alone.

\section{Effect of different treatments on tissue TNF- $\alpha$ (Table 2)}

Administration of STZ to rats induced significant increase in tissue TNF- $\alpha$ compared to the normal control group. Administration of metformin or resveratrol induced significant decrease in tissue TNF- $\alpha$ compared to STZ-treated group. The decrease in tissue TNF- $\alpha$ was more significant with metformin/resveratrol group compared to the use of each of these drugs alone.

\section{Effect of different treatments on tissueTGF- $\beta 1$ (Table 2)}

Table 1: The effect of different treatments on blood urea, serum creatinine, creatinine clearance, serum fasting glucose and glycosylated $\mathrm{Hb}$ in the studied groups

\begin{tabular}{|l|l|l|l|l|l|}
\hline & Group I Control & Group II STZ & $\begin{array}{l}\text { Group III STZ+ } \\
\text { Metformin }\end{array}$ & $\begin{array}{l}\text { Group IV STZ+ } \\
\text { Resveratrol }\end{array}$ & $\begin{array}{l}\text { Group V } \\
\text { STZ+ Metformin + } \\
\text { Resveratrol }\end{array}$ \\
\hline $\begin{array}{l}\text { Blood urea } \\
\mathrm{mg} / \mathrm{dl}\end{array}$ & $21.2 \pm 0.67$ & $78.12 \pm 2.8^{\mathrm{a}}$ & $37.41 \pm 2.77^{\mathrm{b}}$ & $42.14 \pm 2.23^{\mathrm{b}}$ & $31.4 \pm 2.15^{\mathrm{bcd}}$ \\
\hline $\begin{array}{l}\text { Serum creatinine } \\
\mathrm{mg} / \mathrm{dl}\end{array}$ & $0.25 \pm 0.03$ & $2.23 \pm 0.04^{\mathrm{a}}$ & $1.09 \pm 0.03^{\mathrm{b}}$ & $1.17 \pm 0.03^{\mathrm{b}}$ & $0.77 \pm 0.02^{\mathrm{bcd}}$ \\
\hline $\begin{array}{l}\text { Creatinine clear- } \\
\text { ance }\end{array}$ & $1.24 \pm 0.02$ & $0.34 \pm 0.03^{\mathrm{a}}$ & $0.81 \pm 0.04^{\mathrm{b}}$ & $0.79 \pm 0.05^{\mathrm{b}}$ & $1.07 \pm 0.05^{\mathrm{bcd}}$ \\
(ml/min/day) & & & & & \\
\hline $\begin{array}{l}\text { Serum fasting } \\
\text { glucose }\end{array}$ & $119.11 \pm 2.31$ & $464.6 \pm 10.9^{\mathrm{a}}$ & $177.42 \pm 3.07^{\mathrm{b}}$ & $205.35 \pm 3.06^{\mathrm{b}}$ & $147.2 \pm 3.25^{\mathrm{bcd}}$ \\
\hline $\begin{array}{l}\mathrm{mg} / \mathrm{dl}\end{array}$ & & $16.92 \pm 0.7^{\mathrm{a}}$ & $11.91 \pm 0.6^{\mathrm{b}}$ & $9.8 \pm 0.3^{\mathrm{b}}$ & $7.63 \pm 0.4^{\mathrm{bcd}}$ \\
\hline glycosylated Hb \% & $5.61 \pm 0.2$ & & \\
\hline
\end{tabular}

Values were expressed as mean \pm SEM.

aSignificant compared to control group

b Significant compared to STZ group

c Significant compared to metformin group

d Significant compared to resveratrol group 
Citation: Ahmed M. Kabel, Mohamed S. Omar and Hany M. Borg (2015) Targeting Apoptosis, Advanced Glycation End Products and Transforming Growth Factor- $\beta 1$ by Biguanides and Resveratrol to Ameliorate Experimentally-induced Diabetic Nephropathy. J. Drug 1(1): 1-9. doi: https://doi. org/10.24218/jod.2015.1.

Administration of STZ to rats induced significant increase in tissue TGF- $\beta 1$ compared to the normal control group. Administration of metformin or resveratrol induced significant decrease in tissue TGF- $\beta 1$ compared to STZ-treated group. The decrease in tissue TGF- $\beta 1$ was more significant with metformin/resveratrol group compared to the use of each of these drugs alone.

\section{Effect of different treatments on tissue NO (Table 2)}

Administration of STZ to rats induced significant increase in tissue $\mathrm{NO}$ compared to the normal control group. Administration of metformin or resveratrol induced significant decrease in tissue NO compared to STZ-treated group. The decrease in tissue NO was more significant with metformin/resveratrol group compared to the use of each of these drugs alone.

Effect of different treatments on tissue advanced glycation end products (AGEs) (Table 2)

Administration of STZ to rats induced significant increase in tissue AGEs compared to the normal control group. Administration of metformin or resveratrol induced significant decrease in tissue AGEs compared to STZ-treated group. The decrease in tissue AGEs was more significant with metformin/resveratrol group compared to the use of each of these drugs alone.

\section{Effect of different treatments on tissue GSH(Table 2)}

Administration of STZ to rats induced significant decrease in tissue GSH compared to the normal control group. Administration of metformin or resveratrol induced significant increase in tissue GSH compared to STZ-treated group. The increase in tissue GSH was more significant with metformin/resveratrol group compared to the use of each of these drugs alone.

\section{Effect of different treatments on tissue caspase-3 activity} (Table 2)

Administration of STZ to rats induced significant decrease in tissue caspase- 3 activity compared to the normal control group. Administration of metformin or resveratrol induced significant increase in tissue caspase-3 activity compared to STZ-treated group. The increase in tissue caspase-3 activity was more significant with metformin/resveratrol group compared to the use of each of these drugs alone.

\section{Histopathological results}

In the control group, the histopathological examination of kidney tissue showed, normal appearance of the glomeruli \& tubules (Figure 1). Administration of STZ resulted in severe glomerulosclerosis and cellular infiltration, interstitial fibrosis, tubular dilatation, casts and atrophy together with vascular arteriosclerosis and significant decrease in the apoptotic index compared to the control group (Table 3, Figure 2). Treatment with either metformin or resveratrol resulted in marked decrease inglomerulosclerosis, cellular infilteration and interstitial

Table 2: The effect of different treatments on tissue TNF- $\alpha$, TGF- $\beta_{1}$, NO, AGEs, GSH, caspase-3 activity and kidney weight/body weight ratio in the studied groups

\begin{tabular}{|c|c|c|c|c|c|}
\hline & Group I Control & Group II STZ & $\begin{array}{c}\text { Group III } \\
\text { STZ+ Metformin }\end{array}$ & $\begin{array}{c}\text { Group IV } \\
\text { STZ+Resveratrol }\end{array}$ & $\begin{array}{c}\text { Group V } \\
\text { STZ+ Metformin + } \\
\text { Resveratrol }\end{array}$ \\
\hline $\begin{array}{l}\text { Tissue TNF- } \alpha \\
\text { pg/mg protein }\end{array}$ & $82.33 \pm 1.55$ & $225.63 \pm 4.6^{a}$ & $142.63 \pm 4.41^{b}$ & $131.34 \pm 3.4^{\mathrm{b}}$ & $119.12 \pm 3.1^{\mathrm{bcd}}$ \\
\hline 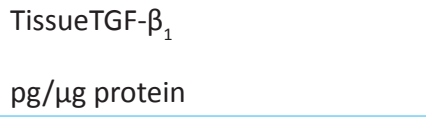 & $3.3 \pm 0.11$ & $10.44 \pm 0.2^{\mathrm{a}}$ & $6.54 \pm 0.31^{\mathrm{b}}$ & $5.61 \pm 0.21^{\mathrm{b}}$ & $4.12 \pm 0.1^{\mathrm{bcd}}$ \\
\hline $\begin{array}{l}\text { Tissue NO } \\
\text { ( } \mu \text { mol/g protein) }\end{array}$ & $1.34 \pm 0.12$ & $3.96 \pm 0.08^{\mathrm{a}}$ & $2.11 \pm 0.09^{b}$ & $1.97 \pm 0.13^{b}$ & $1.68 \pm 0.06^{\mathrm{bcd}}$ \\
\hline Tissue AGEs ( $U / m g$ protein) & $3.18 \pm 0.11$ & $7.87 \pm 0.33^{\mathrm{a}}$ & $4.94 \pm 0.22^{b}$ & $5.35 \pm 0.21^{b}$ & $4.22 \pm 0.13^{\mathrm{bcd}}$ \\
\hline Tissue GSH $(\mu \mathrm{mol} / \mathrm{g})$ & $4.3 \pm 0.04$ & $2.03 \pm 0.07^{a}$ & $3.12 \pm 0.06^{b}$ & $3.41 \pm 0.09^{b}$ & $3.82 \pm 0.08^{\mathrm{bcd}}$ \\
\hline $\begin{array}{l}\text { Tissue caspase } 3 \text { activity } \\
\mathrm{nmol} / \mathrm{mg} \text { protein/min }\end{array}$ & $9.3 \pm 0.41$ & $4.86 \pm 0.24^{\mathrm{a}}$ & $6.85 \pm 0.2^{b}$ & $6.22 \pm 0.25^{b}$ & $7.82 \pm 0.3^{\mathrm{bcd}}$ \\
\hline kidney weight/body weight ratio & $6.04 \pm 0.2$ & $18.91 \pm 0.88^{a}$ & $12.62 \pm 0.5^{b}$ & $11.71 \pm 0.51^{b}$ & $8.13 \pm 0.82^{\mathrm{bcd}}$ \\
\hline
\end{tabular}

Values were expressed as mean \pm SEM.

a Significant compared to control group

b Significant compared to STZ group

c Significant compared to metformin group

${ }^{d}$ Significant compared to resveratrol group 
Citation: Ahmed M. Kabel, Mohamed S. Omar and Hany M. Borg (2015) Targeting Apoptosis, Advanced Glycation End Products and Transforming Growth Factor- $\beta 1$ by Biguanides and Resveratrol to Ameliorate Experimentally-induced Diabetic Nephropathy. J. Drug 1(1): 1-9. doi: https://doi. org/10.24218/jod.2015.1.

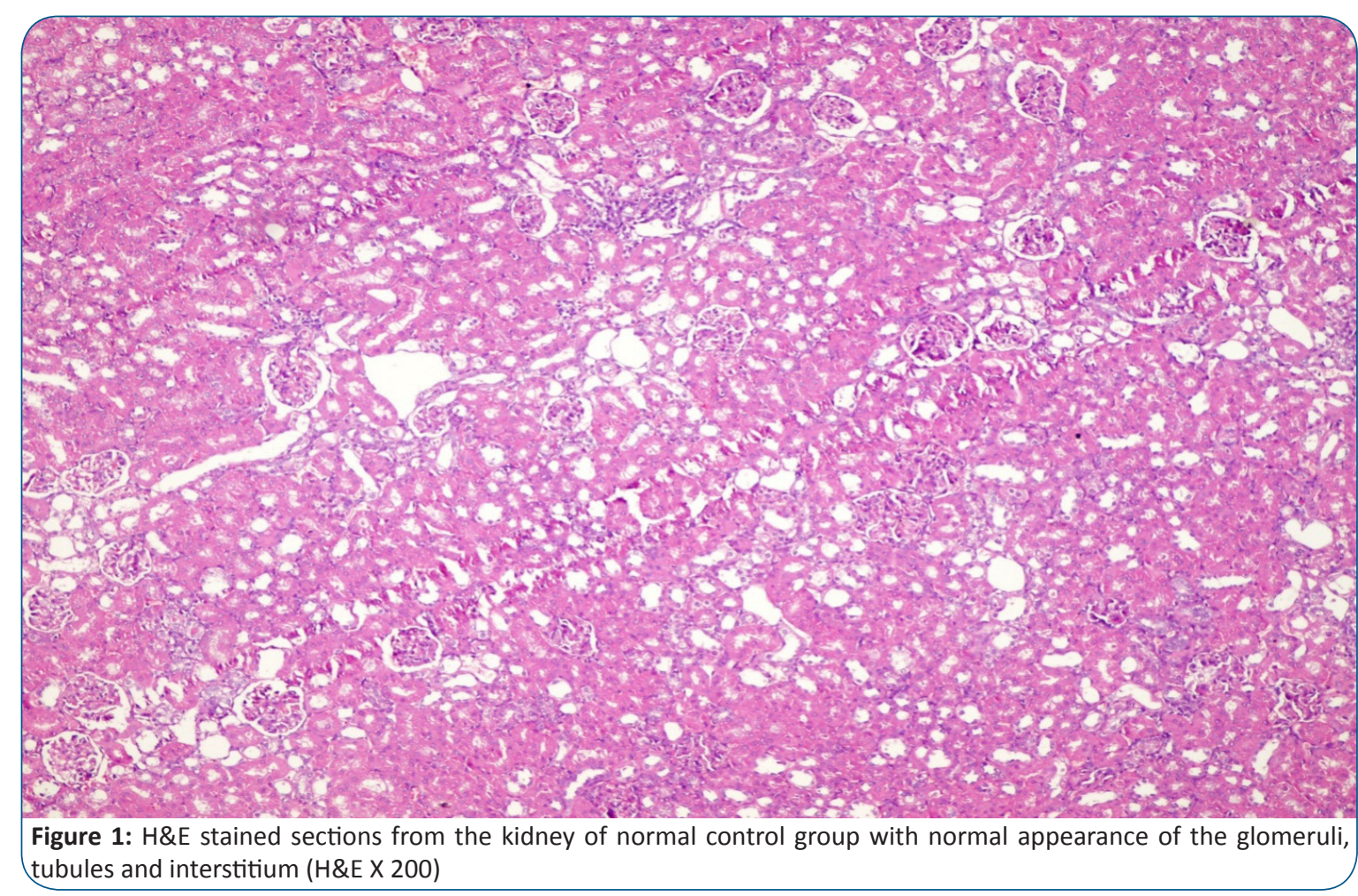

fibrosis, mild dilatation of the tubules with significant increase in the apoptotic index compared to the STZ group (Table 3, Figure $3,4)$. Metformin/resveratrol combination resulted in significant increase in the apoptotic index compared to the use of each of these drugs alone (Table 3, Figure 5).

Table 3: Apoptotic indices in the studied groups

\begin{tabular}{|l|l|}
\hline Group & Apoptotic index (\%) \\
\hline $\mathrm{STZ}$ & $1.4 \pm 0.05$ \\
$\mathrm{STZ}+$ metformin & $4.5 \pm 0.19^{\mathrm{b}}$ \\
$\mathrm{STZ}+$ resveratrol & $3.6 \pm 0.17^{\mathrm{b}}$ \\
$\mathrm{STZ}+$ metformin + resveratrol & $5.3 \pm 0.21^{\mathrm{bcd}}$ \\
\hline
\end{tabular}

Apoptotic index (\%) was calculated for sections of the kidney (values presented as the mean \pm S.E.M. of an average of 10 fields).

bSignificant compared to STZ group

' Significant compared to metformin group

d Significant compared to resveratrol group

\section{Discussion}

$\mathrm{DN}$ is the most common cause of end-stage renal disease and is one of the leading causes of morbidity and mortality in patients with diabetes. It is initially characterized by glomerular haemodynamic abnormalities that lead to glomerular hyperfiltration which overtime progress to glomerular structural damage evidenced by microalbuminuria, proteinuria, decreased glomerular filtration rate and end-stage renal failure [20]. DN occurs as a result of the deleterious effects of both metabolic and hemodynamic insults, which at the cellular level lead to the activation of intracellular signaling pathways and transcription factors, thus triggering the production and release of cytokines, and growth factors such as TGF- $\beta$, increased NO production and accumulation of AGEs which mediate and/or amplify the renal damage. This ultimately leads to the structural and functional features characteristic of DN [21,22]. In the present study, the administration of STZ to rats induced a model of DN manifested as an increase in serum fasting glucose, blood urea, serum creatinine, glycosylated $\mathrm{Hb}$, tissue TNF- $\alpha$, tissue TGF- $\beta 1$, tissue AGEs, tissue $\mathrm{NO}$ and kidney weight/body weight ratio with significant decrease in creatinine clearance, tissue GSH and tissue caspase- 3 activity with marked histopathological changes manifested by massive glomerulosclerosis, interstitial fibrosis, tubular dilatation, casts, atrophy and significant decrease in the apoptotic index compared to the normal control group. These results are in agreement with other studies that indicated that exposure to STZ causes biochemical and histopathological features of DN $[1,3,9]$.

Eleazu et al. [23] reported that STZ can selectively damage the insulin-producing $\beta$-cells in the pancreas resulting in hyperglycemia which is considered as the main cause of progression and complications of DN. It was suggested that DN was associated with activation of several signal pathways, including nuclear factor kappa $\mathrm{B}(\mathrm{NF}-\mathrm{\kappa B})$ and mitogen-activated protein kinase (MAPK). These pathways lead to overexpression of the genes encoding growth factors such as TGF- $\beta 1$. Moreover, both oxidative stress and proinflammatory cytokines were incriminated in the pathogenesis of DN [4]. Also, AGEs stimulate mesangial cells and increase production of extracellular matrix proteins such as fibronectin, enhance production of reactive oxygen species and NO, stimulate intracellular molecules such as NF- $\kappa \mathrm{B}, \mathrm{MAPK}$ and cytokines which play an important role in the progression of $\mathrm{DN}[20,24]$.

Metformin is an oral anti-diabetic drug that is used, along with other drugs, in treatment of type II diabetes mellitus. Recent 
Citation: Ahmed M. Kabel, Mohamed S. Omar and Hany M. Borg (2015) Targeting Apoptosis, Advanced Glycation End Products and Transforming Growth Factor- $\beta 1$ by Biguanides and Resveratrol to Ameliorate Experimentally-induced Diabetic Nephropathy. J. Drug 1(1): 1-9. doi: https://doi. org/10.24218/jod.2015.1.
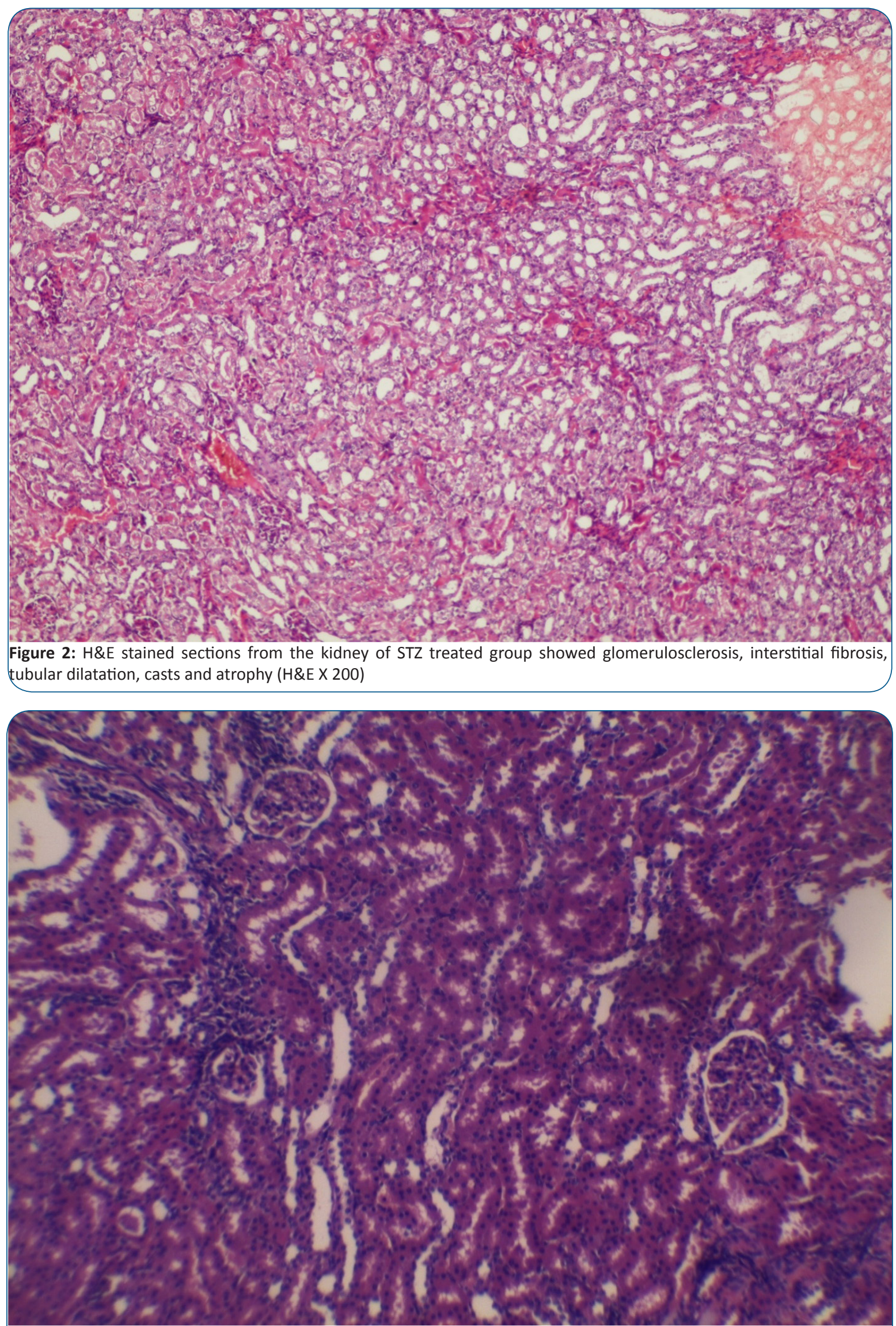

Figure 3: H\&E stained sections from the kidney of STZ+ Metformin treated group with apparently normal glomeruli, mild interstitial fibrosis and minimal tubular necrosis (H\&E X 200) 
Citation: Ahmed M. Kabel, Mohamed S. Omar and Hany M. Borg (2015) Targeting Apoptosis, Advanced Glycation End Products and Transforming Growth Factor- $\beta 1$ by Biguanides and Resveratrol to Ameliorate Experimentally-induced Diabetic Nephropathy. J. Drug 1(1): 1-9. doi: https://doi. org/10.24218/jod.2015.1.

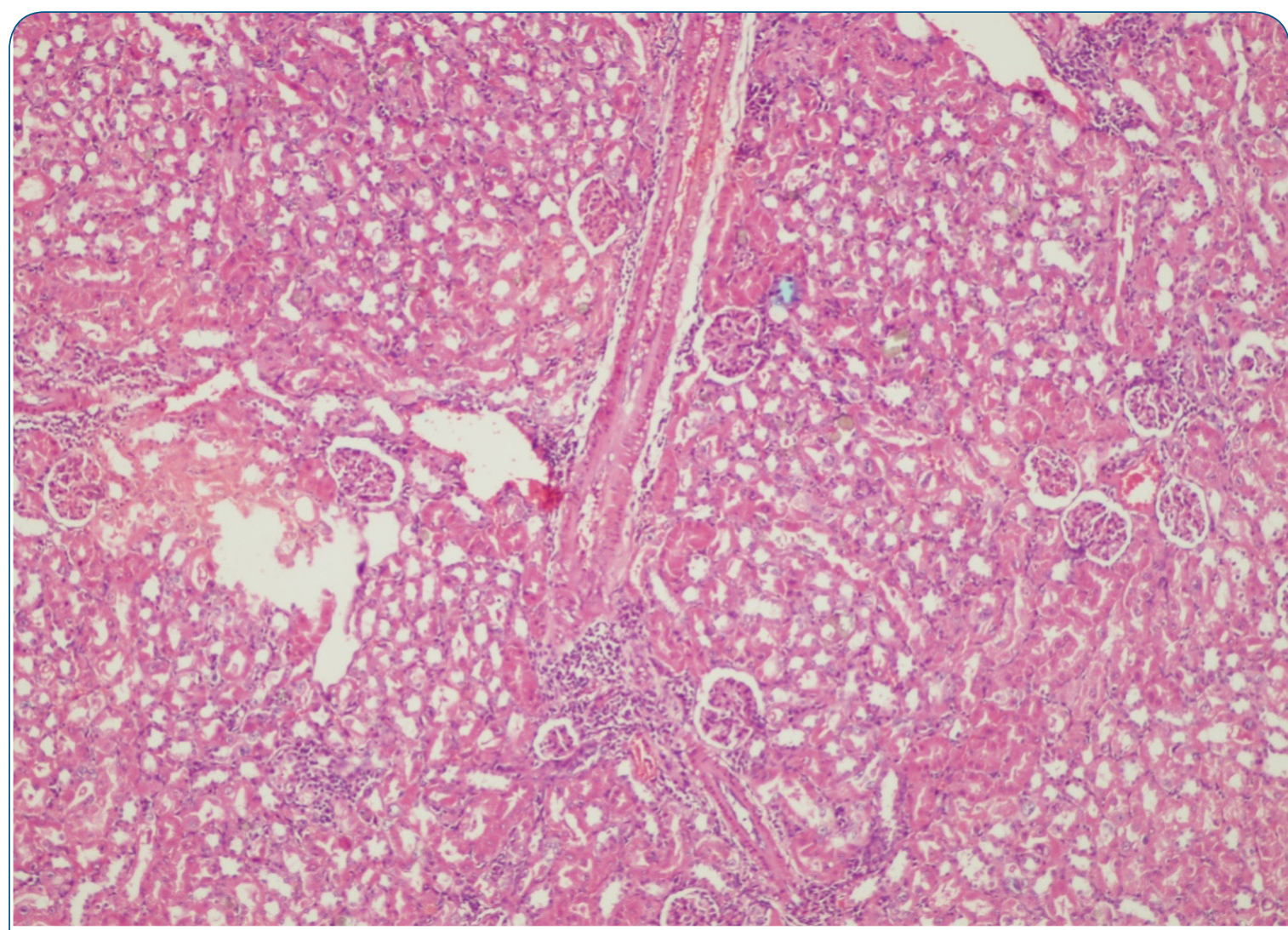

Figure 4: H\&E stained sections from the kidney of STZ + Resveratrol treated group with marked decrease in glomerulosclerosis, cellular infilteration and interstitial fibrosis with mild dilatation of the tubules (H\&E X 200)

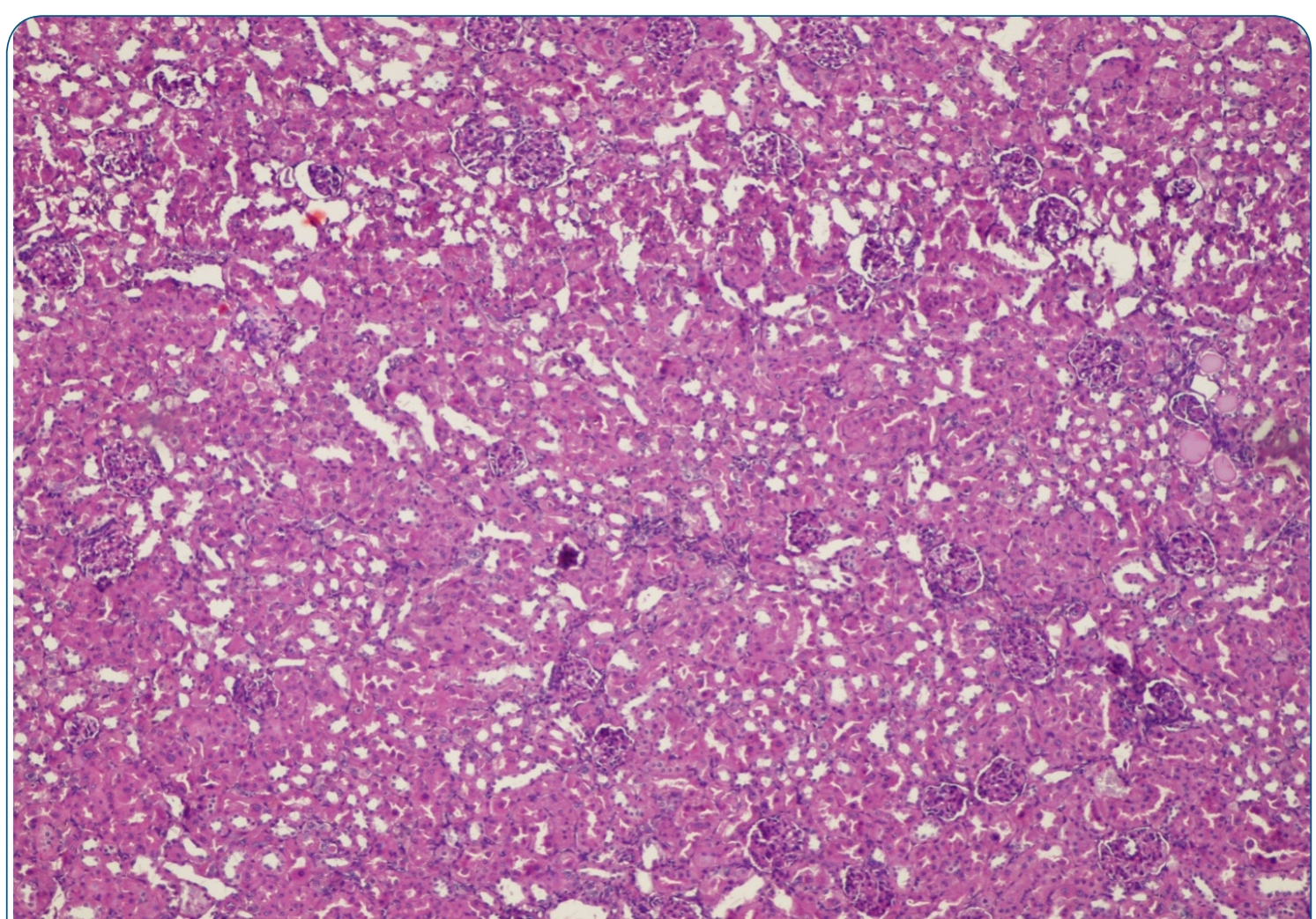

Figure 5: H\&E stained sections from the kidney of STZ+metformin+resveratrol treated group with minimal glomerulosclerosis, minimal cellular infilteration and mild dilatation of the tubules (H\&E X 200) 
Citation: Ahmed M. Kabel, Mohamed S. Omar and Hany M. Borg (2015) Targeting Apoptosis, Advanced Glycation End Products and Transforming Growth Factor- $\beta 1$ by Biguanides and Resveratrol to Ameliorate Experimentally-induced Diabetic Nephropathy. J. Drug 1(1): 1-9. doi: https://doi. $\operatorname{org} / 10.24218 /$ jod.2015.1.

studies showed that metformin has antioxidant and antiinflammatory properties which may play a role in the protection against DN $[9,25]$ which was in agreement with the results of the present study which showed that administration of metformin resulted in decrease in serum fasting glucose, blood urea, serum creatinine, glycosylated $\mathrm{Hb}$, tissue TNF- $\alpha$, tissue TGF- $\beta 1$, tissue AGE, tissue $\mathrm{NO}$ and kidney weight/body weight ratio with significant increase in creatinine clearance, tissue GSH and tissue caspase- 3 activity with improvement of the histopathological picture and apoptotic index compared to STZ-treated group.

The therapeutic action of metformin is attributed mainly to its effects on the hepatocytes, with decreased glucose production and on the muscle cells, with enhanced glucose uptake [26]. Recently, Chakraborty et al. [27] have demonstrated that metformin restores the antioxidant defense mechanisms, enzymatic activity and inflammatory parameters, and improves the status of oxidative and nitrosative stress altered in DM. Alhaider et al.[9] reported that metformin ameliorates $\mathrm{DN}$ by modulation of oxidative stress markers at the level of gene expression, with consequent improvement in mitochondrial function and energy production and blocks the induction of proinflammatory cytokines such as TNF- $\alpha$ and IL-6 genes. Moreover, metformin can affect the carbonyl stress which prevents AGEs formation and improves the free radical defense system [28]. Also, metformin was found to decrease the expression of growth factors such as TGF- $\beta 1$ which plays an important role in the pathogenesis of DN [29].

Resveratrol is a polyphenolic natural compound that exhibited a variety of health benefits including antioxidant, anti-proliferative, anti-inflammatory, antiplatelet, anticancer and cardioprotective properties [30]. There has been strong evidences that resveratrol may act as an antioxidant through enhancing the activity of the antioxidant enzymes and inhibiting cyclooxygenase-2 activity. Recently, resveratrol had been reported to have antihyperglycemic effects in experimental diabetes, which is mediated by modulating the activities of the key carbohydrate metabolizing enzymes in the hepatic and renal tissues of experimental diabetic rats $[3,31]$. These studies are in accordance with the results of the present study where administration of resveratrol resulted in significant decrease in serum fasting glucose, blood urea, serum creatinine, glycosylated $\mathrm{Hb}$, tissue TNF- $\alpha$, tissue TGF$\beta 1$, tissue AGE, tissue NO and kidney weight/body weight ratio with significant increase in creatinine clearance, tissue GSH and caspase-3 activity with improvement of the histopathological picture and apoptotic index compared to STZ-treated group.

Chang et al. [4] reported that resveratrol retards progression of DN through modulation of oxidative stress, proinflammatory cytokines and AMP-activated protein kinase.Kitada et al. [32] found that resveratrol improves oxidative stress and protects against DN through normalization of $\mathrm{Mn}$-superoxide dismutase dysfunction and restoration of tissue GSH level. Also, resveratrol was found to suppress the augmented TGF- $\beta /$ smad and ERK1/2 signaling in STZ-induced diabetic rats[24]. Moreover, resveratrol was demonstrated to affect oxidative stress markers such as malondialdehyde and GSH and antioxidant enzymes such as superoxide dismutase and catalase in the renal tissues of diabetic rats. Resveratrol was reported to alleviate diabetic vasculopathy through attenuation of AGE-receptor for AGE signaling pathway, inhibition of AGE-induced mesangial cell proliferation which represents an important factor in the pathogenesis of $\mathrm{DN}$ and arresting cells in the $S$ phase of the cell cycle [30].

In the present study, metformin/resveratrol combination resulted in significant decrease in serum fasting glucose, blood urea, serum creatinine, glycosylated $\mathrm{Hb}$, tissue TNF- $\alpha$, tissue TGF- $\beta 1$, tissue AGE, tissue $\mathrm{NO}$ and kidney weight/body weight ratio with significant increase in creatinine clearance, tissue GSH and caspase-3 activity with improvement of the histopathological picture and apoptotic index compared to the use of each of these drugs alone. This may be attributed to their combined antihyperglycemic, anti-oxidant and antiinflammatory properties together with their ability to affect TGF- $\beta 1$ and advanced glycation end products together with induction of apoptosis. This was in agreement with Bruckbauer and Zemel[33] who reported that resveratrol combined with metformin may act synergistically on AMP-activated protein kinase-dependent pathways, leading to increased insulin sensitivity, which in turn may reduce the therapeutic doses of metformin needed for treatment of diabetes and may ameliorate its complications including DN. Moreover, Movahed et al. [34] found that the antihyperglycemic effect of resveratrol had an additive effect when combined with metformin in treatment of type-2 diabetes mellitus.

\section{Conclusion}

In conclusion, the present study demonstrated the protective effect of each of resveratrol, and metformin alone and in combination on STZ-induced DN in rats due to their antihyperglycemic, antiinflammatory and antioxidant properties together with their inhibitory effects on AGEs and TGF- $\beta 1$ in renal tissues and induction of apoptosis. So, it is recommended to use metformin/ resveratrol combination in diabetic patients to protect against diabetic nephropathy.

\section{References}

1. Choi YE, Ahn SK, Lee WT, Lee JE, Park SH, Yoon BB, et al. Soybeans Ameliorate Diabetic Nephropathy in Rats. eCAM. 2010; 7(4):433440. doi:10.1093/ecam/nen021.

2. Valko M, Leibfritz D, Moncola J, CroninM, Mazura M, Telser J. Free radicals and antioxidants in normal physiological functions and human disease. Int J Biochem Cell Biol. 2007; 39(1):44-84.

3. Palsamy $P$, Subramanian S. Modulatory effects of resveratrol on attenuating the key enzymes activities of carbohydrate metabolism in Streptozotocin-nicotinamide-induced diabetic rats. Chem Biol Interact. 2009; 179(2-3):356-62. doi: 10.1016/j.cbi.2008.11.008.

4. Chang CC, Chang CY, Wu YT, Huang JP, Yen TH, Hung LM. Resveratrol retards progression of diabetic nephropathy through modulations of oxidative stress, proinflammatory cytokines, and AMP-activated protein kinase. J Biomed Sci. 2011; 18(1):47-53.doi: 10.1186/14230127-18-47.

5. Kim MY, Lim JH, Youn HH, Hong YA, Yang KS, Park HS, et al. Resveratrol prevents renal lipotoxicity and inhibits mesangial cell glucotoxicity in a manner dependent on the AMPK-SIRT1-PGC1 $\alpha$ axis in db/db mice. Diabetologia. 2013; 56(1):204-17.doi: 10.1007/ s00125-012-2747-2.

6. El-Mir MY, Detaille D, Villanueva GR. Neuroprotective role of antidiabetic drug metformin against apoptotic cell death in primary cortical neurons. J Mol Neurosci. 2008; 34(1):77-87. 
Citation: Ahmed M. Kabel, Mohamed S. Omar and Hany M. Borg (2015) Targeting Apoptosis, Advanced Glycation End Products and Transforming Growth Factor- $\beta 1$ by Biguanides and Resveratrol to Ameliorate Experimentally-induced Diabetic Nephropathy. J. Drug 1(1): 1-9. doi: https://doi. org/10.24218/jod.2015.1.

7. Morales A, Detaille $D$, Prieto $M$, Puente A, Briones $E$, Arevalo $M$, et al. Metformin prevents experimental gentamicin-induced nephropathy by a mitochondria-dependent pathway. Kidney International. 2010; 77(10):861-869.doi: 10.1038/ki.2010.11.

8. Nasri H, Rafieian-Kopaei M. Metformin: Current knowledge. J Res Med Sci. 2014; 19(7):658-664.

9. Alhaider AA, Korashy HM, Sayed-Ahmed MM, Mobark M, Kfoury $H$, Mansour MA. Metformin attenuates streptozotocin-induced diabetic nephropathy in rats through modulation of oxidative stress genes expression. Chem Biol Interact. 2011; 192(3):233-242. doi: 10.1016/j.cbi.2011.03.014.

10. Lingelbach LB, Mitchell AE, Rucker RB, McDonald RB. Accumulation of advanced glycation endproducts in aging male Fischer 344 rats during long-term feeding of various dietary carbohydrates. J Nutr. 2000; 130(5):1247-55.

11. Trinder P. Determination of glucose in blood using glucose oxidase with an alternative oxygen acceptor. Ann Clin Biochem. 1969; 6:2425.

12. Patton CJ, Crouch SR. Spectrophotometric and kinetic investigation of the Berthelot reaction for the determination of ammonia. Anal Chem. 1977; 49:464-469.

13. Henry RJ. Determination of serum creatinine. In: Clinical chemistryprinciples and techniques. 2nd ed. Hagerstown, MD, USA: Harper andRow; 1974. p. 525.

14. Cockroft DW, Gault MH. Prediction of creatinine clearance from serum creatinine. Nephrology. 1976; 16(1):31-41.

15. Cortas N, Wakid NW. Determination of inorganic nitrate in serum and urine by a kinetic cadmium-reduction method. Clin Chem. 1990; 36(8Pt1):1440-1443.

16. Beutler E, Durom O, Kelly BM. Improved method for the determination of blood glutathione. J Lab Clin Med. 1963; 61:882888.

17. Lowry OH, Rosebrough, NJ, Farr AL, Randall RJ. Protein measurement with Folin phenol reagent. J Biol Chem. 1951; 193(1):265-275.

18. Gurtu V, Kain SR, Zhang G. Fluorometric and colorimetric detection of caspase activity associated with apoptosis. Anal Biochem. 1997; 251(1):98-102.

19. Staunton MJ, Gaffney EF. Tumor type is a determinant of susceptibility to apoptosis. Am J Clin Pathol. 1995; 103(3):300-307.

20. Soldatos G, Cooper ME. Diabetic nephropathy: important pathophysiologic mechanisms. Diabetes Res Clin Pract. 2008; 82(Suppl 1):75-79. doi: 10.1016/j.diabres.2008.09.042.

21. David S, Peter M. Understanding Diabetic Nephropathy - Is There a Genetic Susceptibility?. European Endocrinology. 2008; 4(2):66-9.

22. Duran-Salgado MB, Rubio-Guerra AF. Diabetic nephropathy and inflammation. World J Diabetes. 2014; 5(3):393-398.

23. Eleazu CO, Eleazu KC, Chukwuma S, Essien UN. Review of the mechanism of cell death resulting from streptozotocin challenge in experimental animals, its practical use and potential risk to humans. J Diabetes Metab Disord. 2013; 12(1):60. doi: 10.1186/2251-6581-12-60.
24. Chen H, Hung C, Hsu H, Jing H, Yang W, Chen K. Resveratrol ameliorates early diabetic nephropathy associated with suppression of augmented TGF- $\beta /$ smad and ERK1/ 2 signaling in streptozotocininduced diabetic rats. Chem Biol Interact. 2011; 190(1):45-53.doi: 10.1016/j.cbi.2011.01.033.

25. Takiyama Y, Harumi T, Watanabe J, Fujita Y, Honjo J, Shimizu N, et al. Tubular Injury in a Rat Model of Type 2 Diabetes Is Prevented by Metformin: A Possible Role of Hypoxia Inducible Factor-1 $\alpha$ Expression and Oxygen Metabolism. Diabetes. 2011; 60(3):981992. doi: $10.2337 / \mathrm{db} 10-0655$.

26. El-Sharkawy AA, Abdelmotaleb GS, Aly MK, Kabel AM. Effect of metformin on sleep disorders in adolescent girls with polycystic ovarian syndrome. J Pediatr Adolesc Gynecol. 2014; 27(6):347-352. doi: 10.1016/j.jpag.2014.01.004.

27. Chakraborty A, Chowdhury S, Bhattacharyya M. Effect of metformin on oxidative stress, nitrosative stress and inflammatory biomarkers in type 2 diabetes patients. Diabetes Res Clin Pract. 2011; 93(1):5662.doi: 10.1016/j.diabres.2010.11.030.

28. Faure P, Wiernsperger N, Polge C, Favier A, Halimi S. Impairment of the antioxidant properties of serum albumin in patients with diabetes: protective effects of metformin. Clin. Sci (Lond). 2008; 114(3):251-256.

29. Viollet B, Guigas B, Garcia N, Leclerc J, Foretz M, Andreelli F. Cellular and molecular mechanisms of metformin: an overview. Clin Sci (Lond). 2012; 122(6):253-270.doi: 10.1042/CS20110386.

30. Jiang B, Li B, Guo L, Song J, Li X, Yang X, et al. Inhibitory effect of resveratrol on advanced glycation end products-induced mesangial cell proliferation. African J Pharmacy Pharmacol. 2012; 6(10):737742.

31. Su HC, Hung LM, Chen JK. Resveratrol, a red wine antioxidant, possesses an insulin-like effect in streptozotocin-induced diabetic rats. Am J Physiol Endocrinol Metab. 2006; 290(6):1339-1346.

32. Kitada M, Kume S, Imaizumi N, Koya D. Resveratrol Improves Oxidative Stress and Protects Against Diabetic Nephropathy Through Normalization of Mn-SOD Dysfunction in AMPK/SIRT1Independent Pathway. Diabetes. 2011; 60(2):634-643. doi: 10.2337/db10-0386.

33. Bruckbauer A, Zemel MB. Synergistic effects of metformin, resveratrol, and hydroxymethylbutyrate on insulin sensitivity. Diabetes Metab Syndr Obes. 2013; 6:93-102. doi: 10.2147/DMSO. S40840.

34. Movahed A, Nabipour I, Louis XL, Thandapilly SJ, Yu L, Kalantarhormozi $M$, et al. Antihyperglycemic Effects of short term resveratrol supplementation in type 2 diabetic Patients. Evid Based Complement Alternat Med. 2013; 851267.doi: 10.1155/2013/851267. 